\title{
Harmonic versus electrocautery in the dissection of gall bladder in laparoscopic cholecystectomy
}

\author{
Nashwan K. Mahjob ${ }^{a}$, Emad Tahir ${ }^{b}$, Samer Alsaffar ${ }^{a}$, Miss Muna M. Ahmad ${ }^{c}$ \\ From the a Department of Surgery, College of Medicine, University of Mosul, Mosul, Iraq, ${ }^{b}$ Department of Surgery, Nineveh \\ College of Medicine, University of Mosul, ' ${ }^{\circ}$ epartment of Community Medicine, College of Medicine, University of Mosul. \\ Correspondence: Nashwan K. Mahjob a .nashwanmahjob@yahoo.com.
}

(Ann Coll Med Mosul 2013; 39 (2): 107-112).

Received: $22^{\text {nd }}$ Feb. 2012; Accepted: $4^{\text {th }}$ Mar. 2013.

\begin{abstract}
Objective: To demonstrate the efficiency and safety of Harmonic scalpel in comparison with electrocautery for gallbladder dissection and hemostasis in laparoscopic cholecystectomy.

Patients and methods: A prospective comparative, study was done at Al-Jamhori Teaching Hospital in Mosul, during the period from $1^{\text {st }}$ of January 2010 to $1^{\text {st }}$ of January 2012. Three hundred and twenty patients underwent laparoscopic cholecystectomy, the following criteria were applied for selection: they had chronic cholecystitis, no complaint at time of operation, age between 25 to 50 years, normal body weight, with American Score of Anesthesia (ASA) of 1 or 2, no previous upper abdominal operation, no, or well controlled hypertension or diabetes, gall bladder wall thickness with less than $6 \mathrm{~mm}$ by preoperative ultrasonography and all the patients were operated by the authors. The patients were divided into two groups according to the instrument used for dissection of gall bladder from its bed, the first group with electrocautery and second group with harmonic scalpel. The time needed for complete dissection and hemostasis started from spreading of Calot's triangle till removal of gall bladder totally from its bed, was recorded. Any intra operative complications: bleeding, gallbladder perforation, slipped stones, or conversion were recorded.

Results: The study included 320 patients, 172 patients belonged to the first group (electrocautery) and 148 patients belonged to second group (harmonic). For the first group, the median time was 17 minutes, the mean time was 17.7 minutes and the mode was 13 minutes, while that for second group, the median time was 14 minutes, with a mean time of 16 minutes and a mode of 14 minutes. Intra-operative bleeding was recorded in $34(20 \%)$ for the first group and $17(11 \%)$ for the second one. Gallbladder perforation was recorded in $26(15 \%)$ patients and slipped stone in $12(7 \%)$ patients in the electrocautery group and 13(9\%) and $5(3 \%)$ respectively in the harmonic group. No common bile duct injury was recorded in either group. Conversion was needed in 4 patients $(1.3 \%), 3(2 \%)$ patients belonged to the first group and one $(06 \%)$ to the second group.

Conclusion: Harmonic scalpel is very safe and effective instrument for dissection of gall bladder and hemostasis in laparoscopic cholecystectomy and can replace electrocautery for this purpose if available at operative theater.
\end{abstract}

Keywords: Laparoscopic cholecystectomy, harmonic scalpel, electrocautery.

$$
\begin{aligned}
& \text { دراسة مقارنة بين القاطع الصوتي والكهربائي في عملية رفع المرارة بالمنظار الجراحي }
\end{aligned}
$$

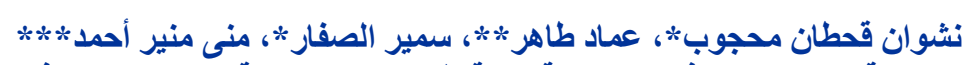

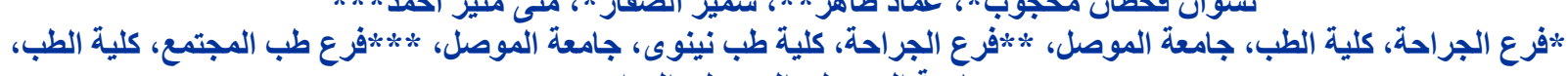

$$
\begin{aligned}
& \text { جامعة الموصل، الموصل، العراق }
\end{aligned}
$$




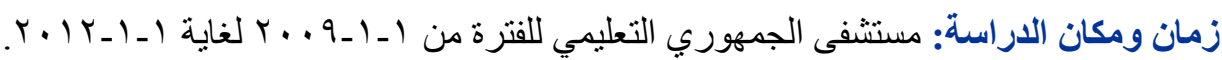
القياسات الإجرائية: ضمّت الدراسة • بr مريضا أجريت لهم عملية رفع المرارة بالمنظار الجراحي من قبل الباحثين وقد تم

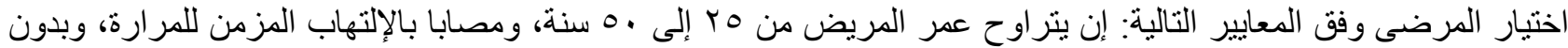

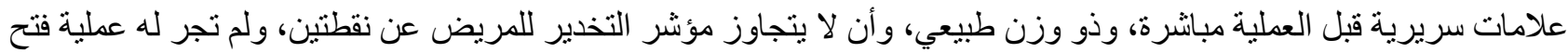

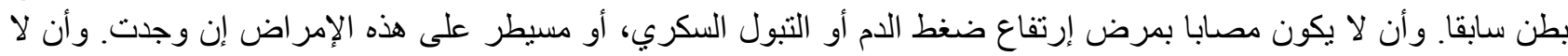

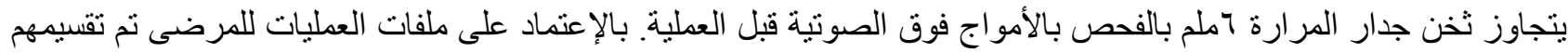

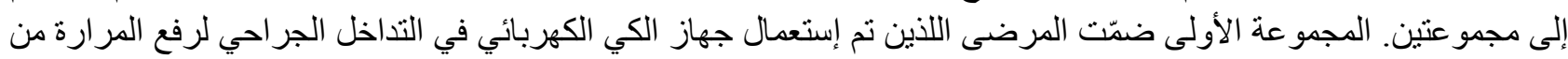
الكبد. بينما ضمّت المجموعة الثانية المرضى اللذين تم إستخدام السكين الصوتي لذلك. تم إحتساب الوقت بالدقائق لإكمال عملية رقي النزوفات والسيطرة على شريان المرارة وقناتها ورفع المرارة كاملا من الكبد. كما تم تسجيل حالات النزوفات وطرق التهب السيطرة عليها كذلل. تم تسجيل حالات إنثقاب المرارة و إنسكاب الحصيات إلى التجويف البطني. وتم تسجيل حالات التحويل إلى

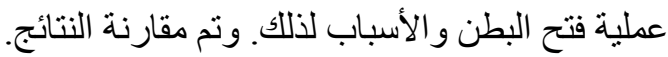

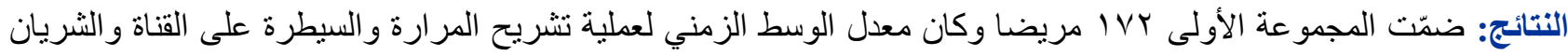

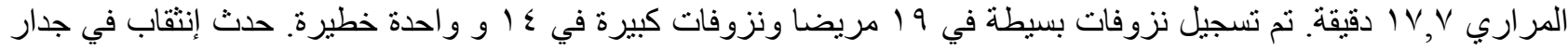

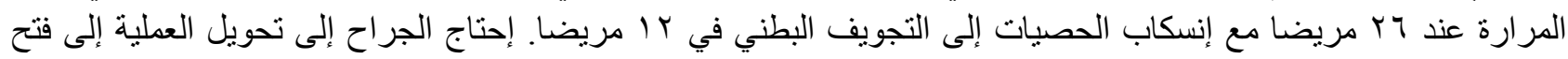

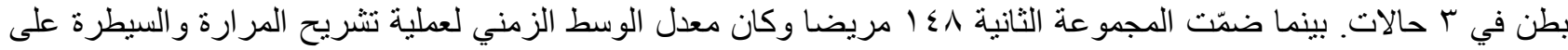

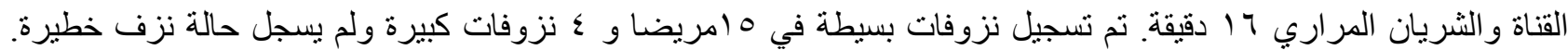

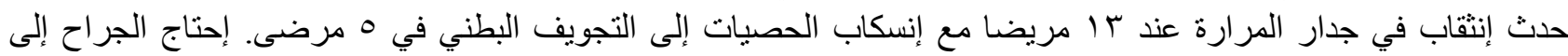
تحويل العملية إلى فتح بطن في حالة و احدة فقط. الإستنتاج: عملية رفع المرارة بالمنظار بإستخدام السكين الصوتي فعالة فئة وأمينة بالمقارنة مع إستخدام جهاز الكي الكهربائي ونحن

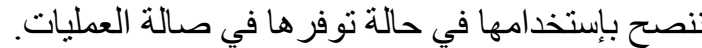
الكلمات الاليلية: رفع المرارة بالمنظار ، جهاز الكي الكهربائي، جهاز السكين الصوتي.

\section{INTRODUCTION}

$\mathrm{V}$ arious surgical equipments have been developed for safe effective and careful dissection of the gallbladder in laparoscopic cholecystectomy, aiming to decrease intra and postoperative complications to a minimum level. ${ }^{1}$ At the present time, in addition to electrocautery, various ultrasonic scalpel, water jet dissectors, laser systems, and specially prepared suction devices have been used. All these equipments can achieve complete hemostasis during dissection with various efficacy. ${ }^{2}$

Electric hook is the most popular instrument that is used to achieve a bloodless operating field in laparoscopic cholecystectomy, however, the use of electric coagulation whether monopolar or bipolar may cause damage to nearby organs i. e, the common bile duct, stomach, or small bowel, ${ }^{3}$ or local complication like liver injury, gallbladder perforation and loss of bile or stones into the peritoneal cavity. ${ }^{4}$ The ultrasonically activated (Harmonic) scalpel was designed as a safe alternative to electrocautery for the hemostatic dissection of tissues, it was introduced into clinical use nearly a decade ago. ${ }^{5}$

The primary use of the Harmonic scalpel in laparoscopic cholecystectomy has been used for the division of the cystic artery and liver bed dissection. This innovative method of cutting tissues was based upon the coagulating and cavitational effects provided by a rapidly vibrating blade contacting various tissues. ${ }^{6}$ The resulting decrease in temperatures, smoke, and lateral tissue damage by using the Harmonic scalpel is a better alternative to more traditional electrocautery. In addition, the elimination of inadvertent, sometimes unrecognized, electrical arcing injuries with their potentially hazardous sequelae supported the role of the Harmonic scalpel as a potentially safer instrument for tissue dissection. ${ }^{6}$ Since its inception, the Harmonic scalpel has gained significant clinician acceptance and applications. ${ }^{7}$

Harmonic scalpel for standard laparoscopic cholecystectomies was not available in Mosul city hospitals before 2010 . 
This study was undertaken to demonstrate the efficiency and safety of the Harmonic scalpel to achieve complete dissection and hemostasis at laparoscopic cholecystectomies in comparison with the traditional electrocautery at Aljamhori Teaching Hospital in Mosul.

\section{PATIENTS AND METHODS}

This is a prospective comparative study. Patients were divided into two groups; in the first group electrocautery was used for dissection, in the second group harmonic knife was used for achieving the dissection. The randomization was done as follows: the first group was operated upon on odd months; the second group was operated upon on even months. The criteria for selection of patients were: age between 25 and 50 years, normal body weight, ASA 1 or 2, elective cholecystectomy, no, or well controlled hypertension or diabetes, no previous upper abdominal surgery, wall thickness of gallbladder less than $6 \mathrm{~mm}$ as shown by ultrasound preoperatively and normal biliary passages. Operative procedures were performed with the patient under general anesthesia and placed in the standard supine, right tilt, reverse-Trendelenburg position. $\mathrm{CO}_{2}$ pneumoperitoneum was achieved by either Veress needle or open method. All procedures were performed through 3 operative ports and a camera port. Dissection of the gallbladder was initiated at the triangle of Calot's with identification, dissection and division of the cystic duct after double clip application, the artery was either clipped or cauterized (in the first group), and was clipped or divided by harmonic scalpel (in the second group). Mobilization of the gallbladder from the liver bed was followed, and subsequent removal of the gall bladder through the umbilicus or epigastric incision was done. The time needed for complete dissection and hemostasis started from spreading of Calot's triangle, controlling the cystic duct and artery till removal of gall bladder totally from its bed, and complete hemostasis were recorded. The mean, time was calculated, any intra-operative complications in form of bleeding, regarding its site (cystic artery, gallbladder bed, other site), severity (minor, major, extensive) and ways of their control were recorded. Severity of bleeding was classified according to the following criteria: minor bleeding means bleeding that needed only one interventional step to stop it without further instrumentation or change of the equipment, major bleeding means bleeding which needed more than one step to control it or further instrumentation or change of the equipment, extensive bleeding means bleeding which needed conversion. Biliary complication in form of gallbladder perforation, slipped stones, common bile duct injury and the way of their management and the time needed to control the complication were also recorded. Conversion was recorded with its indication. The data of both groups were compared with each other and statistically analyzed using the Chi-square and Fisher Exact test.

\section{RESULTS}

The study included 320 patients, there were 222 females and 98 males. One hundred and seventy two patients belonged to the first group (electrocautery) and 148 patients belonged to the second group (harmonic). The age range of all patients was between 25 and 50 years, the median age for the first group was 33 years, and 34 years for the second. The total time range for dissection and hemostasis (dissection of Calot's triangle, clipping cystic duct, dealing with cystic artery) was between 8 and 30 minutes in both groups. For the first group, the mean time was 17.7 minutes, and for second group, was 16 minutes as shown in Table 1.

The cystic duct, in both groups was doubly clipped and divided. The cystic artery was cauterized in $112(65 \%)$ patients in the first group and clipped in 60 (35\%) patients according to surgeon preference, while in second group, cystic artery was cut by the harmonic knife in $89(60 \%)$ and clipped in $59(40 \%)$ patients. Intraoperatve bleeding was recorded in $34(20 \%)$ patients in the first group and in $17(11 \%)$ patients in the second one, as shown in Table 2.

Minor bleeding in the first group was treated by a single touch of electrocautery hook, in the second group, it was controlled by a single touch of harmonic scalpel without significant diference in time. Major bleeding occurred in $14(8 \%)$ patients in the first group, 10 of them needed clipping of the offending bleeding, 3 needed suturing and 4 needed several touches of cauterization. The range of time needed to control major bleeding was 2 to 9 minutes with a mean of 4.5 minutes. Major bleeding occurred in $4(3 \%)$ patients in the 
second group, 2 of them needed clipping of the site of bleeding; suturing, in one case and several touches by the harmonic instrument in one. The range of time needed to control major bleeding was 1 to 7 minutes with a mean of 3.5 minutes. The cystic artery was the site of major bleeding in $10(5.8 \%)$ patients and gallbladder bed in $4(2.3 \%)$ patients in the first group. In the second group, 3 (2\%) patients had major bleeding from cystic artery and one $(0.6 \%)$ patient from the gallbladder bed.

Extensive bleeding that necessitated conversion occurred in one $(0.5 \%)$ patient in the first group and none in the second group.

Biliary trauma in form of gallbladder perforation, slipped stone through gallbladder perforation to the peritoneal cavity, and common bile duct injury is shown in Table 3.

Perforation of gall bladder with slipping of stones in both groups was treated by suction, clipping of site of perforation, retrieving the stones and washing of the gallbladder bed by saline. There was no significant deference in procedure or time needed to control this complication in both groups.

Conversion was needed in 4 patients $(1.3 \%), 3$ (2\%) belonged to the first group due to severe adhesions in 2 patients and extensive bleeding in one patient, and one patient $(0.6 \%)$ in the second group because of unclear anatomy at Calot's triangle due to adhesions.

Table 1. Time needed for dissection and hemostasis in both groups.

\begin{tabular}{lccc}
\hline $\begin{array}{c}\text { Time needed for } \\
\text { dissection and } \\
\text { hemostasis } \\
\text { (minutes) }\end{array}$ & $\begin{array}{c}\text { Electrocautery } \\
(\mathbf{n}=172)\end{array}$ & $\begin{array}{c}\text { Harmonic } \\
(\mathbf{n}=148)\end{array}$ & $\begin{array}{c}\mathbf{P}^{*} \text { - } \\
\text { Value }\end{array}$ \\
\hline$\leq 10$ & No $(\%)$ & $33(22.3)$ & 0.099 \\
$11-15$ & $49(15.1)$ & $56(37.8)$ & 0.076 \\
$16-20$ & $39(22.7)$ & $23(15.5)$ & 0.107 \\
$21-25$ & $36(20.9)$ & $19(12.8)$ & 0.056 \\
$26-30$ & $22(12.4)$ & $17(11.5)$ & 0.722 \\
\hline Total & $172(100.0)$ & $148(100.0)$ & 0.050 \\
\hline Mean \pm SD & $17.7 \pm 6.2$ & $16.0 \pm 6.3$ & \\
\hline * $x^{2}$ test was used & & & \\
\hline
\end{tabular}

${ }^{*} X^{2}$ - test was used.

Table 2. The types of bleeding in both groups.

\begin{tabular}{lccc}
\hline $\begin{array}{c}\text { Type of } \\
\text { bleeding }\end{array}$ & $\begin{array}{c}\text { Electrocautery } \\
\text { No }(\%)\end{array}$ & $\begin{array}{c}\text { Harmonic } \\
\text { No }(\%)\end{array}$ & $\begin{array}{c}\text { P*- } \\
\text { Value }\end{array}$ \\
\hline Minor & $19(11.1)$ & $15(10.1)$ & 0.792 \\
Major & $14(8.1)$ & $4(2.7)$ & 0.035 \\
Extensive & $1(0.6)$ & $0(0.0)$ & 0.538 \\
No Bleeding & $138(80.2)$ & $129(87.2)$ & 0.096 \\
Total & $172(100.0)$ & $148(100.0)$ & 0.135 \\
\hline${ }^{*} X^{2}$-test was used. & & \\
${ }^{* *}$ Exact Fisher test was used. & &
\end{tabular}

Table 3. Biliary trauma in both groups.

\begin{tabular}{lccc}
\hline $\begin{array}{l}\text { Type of biliary } \\
\text { complication }\end{array}$ & $\begin{array}{c}\text { Electrocautery } \\
(\mathrm{n}=172)\end{array}$ & $\begin{array}{c}\text { Harmonic } \\
(\mathrm{n}=148)\end{array}$ & $\begin{array}{c}\mathbf{P}^{*} \text { - } \\
\text { Value }\end{array}$ \\
\hline $\begin{array}{l}\text { Gallbladder } \\
\text { perforation }\end{array}$ & $26(15.1)$ & $13(8.8)$ & 0.084 \\
$\begin{array}{l}\text { Slipped stone } \\
\begin{array}{l}\text { Common bile } \\
\text { duct injury }\end{array}\end{array}$ & $12(6.7)$ & $5(3.4)$ & 0.152 \\
\hline${ }^{*}{ }^{2}$-test was used. & 0 & 0 & \\
DISCUSSION & & &
\end{tabular}

In gallbladder surgery, a decrease in operative blood loss, less local thermal damage to tissue, less gallbladder perforation and common bile duct injury, less intraoperatve time and more cost effectiveness is the aim. This can be achieved when the equipments, techniques, and experience reach the optimum level of requirement. ${ }^{8}$ The ultrasonic generator cuts and coagulates by using low temperatures, lower than those used by electro surgery or lasers. Ultrasonic technology controls bleeding by coaptive coagulation at low temperatures which ranges from 50 to100 degrees Celsius. Vessels are coapted (tamponaded) and sealed by a protein coagulum. Coagulation occurs by means of protein denaturation as the blade couples with protein, denaturing it to form a coagulum which finally contracts to seal small coapted vessels. When the effect is prolonged, secondary heat is produced that seals larger vessels. By contrast, electrosurgery and lasers provide the technique of obliterative coagulation i.e, coagulation by burning at higher temperatures $\left(150-400^{\circ} \mathrm{C}\right)$. Blood and tissue are desiccated and oxidized (charred), forming Escher that covers and seals the bleeding area. ${ }^{8-10}$ Re-bleeding can be hazardous when blades are removed during electrosurgery and they stick to tissue disrupting the escher. ${ }^{11}$ Furthermore, the ultrasonic scalpel demonstrates an approximately one millimeter zone of denatured tissue around the ultrasonic incision similar to the lateral energy dispersion demonstrated with ultrasonic instrumentation in porcine models. This finding compares favorably with the 0.24 to $15.0 \mathrm{~mm}$ range of thermal energy damage associated with electrocautery. ${ }^{12}$

In our series there was a decrease in number of gall bladder perforation from $15 \%$ to $8 \%$ ( $P$ value 0.084 ), as well as slipped stones from $6.7 \%$ to $3.4 \%$ ( $P$ value 0.152 ), this is attributed to a very small perforation induced by harmonic knife in 
comparison with perforation caused by electrocautery. A randomized clinical trial of ultrasonic versus electrocautery dissection of the gallbladder in laparoscopic cholecystectomy was conducted by Janssen I et al ${ }^{13}$ on 200 patients. They reported that with the use of ultrasonic generators in laparoscopic cholecystectomy the incidence of gallbladder perforation dropped down drastically and the operation progressed more smoothly.

The ultrasonic dissector dissolved the fat, which was rapidly cleared up at the Calot's triangle allowing the cystic duct and artery to be bared with less risk of injury. ${ }^{14}$ Furthermore, because of the minimal thermal dispersion, the use of the harmonic reduces the risk of injuries. ${ }^{15}$ In a single randomized clinical trial that involved 200 patients undergoing a laparoscopic cholecystectomy procedure, a small but statistically significant difference in blood loss was detected. ${ }^{16}$ In our study there was a decrease in the percentage of minor as well as major bleeding, definitely due to less trauma produced by harmonic scalpel.

A significant difference in surgery time in favor of ultrasonic instrumentation was found in Bessa $\mathrm{S}$ et al study, ${ }^{17}$ which may be attributed to less number of extraction and insertion of different instruments in addition, the electronically activated harmonic scalpel produces almost no smoke, thus, the visibility of the operative field is preserved during the whole procedure, and there is no need to remove the smoke and to recreate the pneumoperitoneum, or to repeatedly clean the lens. In our study in relation to the mean time of dissection of gall bladder from its bed including the control of cystic duct and artery, which are the main procedures during laparoscopic cholecystectomy, there was no significant difference in time between the 2 groups. This may be due to that the authors had less experience with harmonic scalpel and that others showed decrease in the operating time by using clipless technique. However, the statistical significance of short time does not necessarily mean a clinical advantage, especially when operating time is largely dependent on the training and expertise of individual surgeons. Most surgeons can improve their use of monopolar electro-surgery, which will shorten their operating time, while ultrasonic dissection by the inexperienced hands may well be a long, unsafe dissection procedure. ${ }^{18}$

We used harmonic device for the control of cystic artery in $60 \%$ of cases only because of less personal experience, especially at the beginning of our research; however, the excellent vascular control has built up the confidence for us to use it more frequently later on. Power $\mathrm{C}^{19}$ concluded that laparoscopic cholecystectomy performed with the harmonic scalpel is feasible and effective, operating time and blood loss are minimal, and the conversion rate is low (3.9\%). There were no bile duct injuries which made dissection easier, thereby helping to reduce operative time and lower the need for conversion to open surgery. In Abrar $\mathrm{H}$ study $^{20}$ with 100 patients underwent laparoscopic cholecystectomy using harmonic scalpel, gall bladder perforation occurred in $2.7 \%$ and slipped stone in $1.8 \%$. No notable or uncontrolled hemorrhage was recorded, and there was no injury to common bile duct or post-operative biliary discharge. Conversion to open surgery was required in $2(1.81 \%)$ cases only on account of difficulty in dissection and failure to proceed. Average dissection time was 40 minute ranging from 17 to 70 minutes and there was no mortality in his study. Conversion needed in our study in 4 patients $(1.3 \%), 3(2 \%)$ patients belonged to the first group and one (06\%) patient to the second group. This very low percentage may be due to exclusion of acute cholecystitis from the study. We did not use harmonic device for the cystic duct control in all cases, instead we used the conventional clipping method.

However, the description of one hundred cases by Westervelt $\mathrm{J}^{21}$ and one hundred cases by Tebala GD. ${ }^{21}$ as well as Amarin $\mathrm{N}^{22}$ with reference to total harmonic dissection [clipless surgery] gives sound evidence of the effectiveness and safety of this instrument. ${ }^{23}$ The main disadvantage of ultrasonic dissection is instrument cost, which is particularly true if the surgical unit is equipped with reusable instruments. Nevertheless, some authors believe that compared with combined cost of using multiple disposable instruments (scissors, a clipper, an electrocautery hook, and a grasper), the harmonic scalpel may provide a cost-effective option. $^{22}$ However, the cost issue is relevant only on the assumption that disposable technology is used for monopolar electrocautery. By knowing 
that both ultrasonic and monopolar electro surgery are now reusable instruments, making cost comparisons more difficult. It is therefore advocated that further comparative studies should be carried out preferably within a single health system or even within a single health institution. Fortunately, in our hospital all the operation expenses are covered by the government.

In conclusion, the introduction of harmonic device improved the results, and had not only alleviated the fears associated with electrocautery trauma but made laparoscopic cholecystectomy a safer procedure.

\section{REFERENCES}

1. Schröder $\mathrm{T}$, Hasselgren $\mathrm{PO}$, Brackett $\mathrm{K}$, et al. Techniques of liver resection: Comparison of suction knife, ultrasonic dissector and contact neodymium-YAG laser. Arch Surg 1987; 122: 1166-1171.

2. Gozen AS, Teber D, Rassweiler J. Principles and initial experience of a new device for dissection and hemostasis. Minim Invasive Ther Allied Technol 2007; 16:58-65.

3. Schlumpf R, Klotz HP, Wehrli $\mathrm{H}$, et al. Laparoskopische Chirurgie in der Schweiz. Chirurgie 1993; 64: 307-313.

4. Lee CL, Huang KG, Wang CJ, Lee PS. Laparoscopic radical hysterectomy using pulsed bipolar system: comparison with conventional bipolar electrosurgery. Gynecol Oncol. 2007; 105:620-624.

5. Cuschieri A. How I do it, laparoscopic cholecystectomy. J. R. Coll. Surg. Edinb. 1999; 44:187-192.

6. Laparoscopic tissue approximation techniques in Text book of practical laparoscopic surgery. $3^{\text {rd }}$ ed. New Delhi: Jaypee Brothers; 2008. p.115.

7. Sietses C, Eijsbouts Q, von Blomberg B, Cuesta M. Ultrasonic energy vs monopolar electrosurgery in laparoscopic cholecystectomy. Surgical Endoscopy 2001;15(1):69-71.

8. Park AE, Mastrangelo MJ Jr, Gandsas A, Chu U, Quick NE. Laparoscopic dissecting instruments. Semin Laparosc Surg. 2001;8(1):42-52.

9. Brent $\mathrm{M}$, Luba N, Estok RN. Ultrasonic and Nonultrasonic Instrumentation. A Systematic Review and Meta-analysis. Arch Surg. 2008;143(6):592-600.

10. James I. Clipless Cholecystectomy: Broadening the Role of the Harmonic Scalpel. JSLS, Journal of the
Society of Laparoendoscopic Surgeons 2004;8(3): 283285.

11. Landman J, Kerbl K, Rehman J, Andreoni C, Humphrey PA, Collyer W. Evaluation of a vessel sealing system, bipolar electrosurgery, harmonic scalpel, titanium clips, endoscopic gastrointestinal anastomosis vascular staples and sutures for arterial and venous ligation in a porcine model. J Urol 2003; 169:697-700.

12. Cengiz $Y$, Jänes $A$, Grehn $A$, Israelsson $L A$. Randomized trial of traditional dissection with electrocautery versus ultrasonic fundus-first dissection in patients undergoing laparoscopic cholecystectomy. Br J Surg. 2005;92(7):810-813.

13. Janssen I. Swank D. Boonstra B. Knipscheer J. Randomized clinical trial of ultrasonic versus electrocautery dissection of the gallbladder in laparoscopic cholecystectomy, British Journal of Surgery 2003;93(5):652-657.

14. Albert Wetter L, John H, Gerald K. The Ultrasonic Dissector Facilitates Laparoscopic Cholecystectomy. Arch Surg. 1992;127(10):1195-1199.

15. Roberta G, Chiara F, Stefano Z. Laparoscopic Cholecystectomy With Harmonic Scalpel. JSLS. 2010 Jan-Mar; 14(1): 14-19.

16. Simoyiannis $\mathrm{T}$, Jabarin $\mathrm{M}$, Glantzounis $\mathrm{G}$, et al. Laparoscopic cholecystectomy using ultrasonically activated coagulating shears. Surg Laparosc Endosc. 1998;8(6):421-424.

17. Bessa S, Al-Fayoumi T, Katri K, Awad A. Clipless laparoscopic cholecystectomy by ultrasonic dissection. J Laparoendosc Adv Surg Tech. 2008;18(4):593-598.

18. Tara L, Fran W. Early detection of complications after laparoscopic surgery: summary of a safety report from the National Patient Safety Agency. BMJ 2011; 342:c7221.

19. Power C, Maguire D, McAnena OJ, Calleary J. Use of the ultrasonic dissecting scalpel in laparoscopic cholecystectomy. Surg Endosc. 2000;14(11):1070-3.

20. Abrar Hussain Z, Abdul Haleem S. Use of harmonic scalpel in laparoscopic cholecystectomy. Pakistan armed forces medical journal 2011 March;1:233.

21. Westervelt J. Clipless cholecystectomy: broadening the role of the harmonic scalpel. JSLS. 2004; 8: 283-5.

22. Tebala GD. Three-port laparoscopic cholecystectomy by harmonic dissection without cystic duct and artery clipping. Am J Surg. 2006 ;191:718-20.

23. Amarin NS. Harmonic Scalpel and Clipless Cholecystectomy World Journal of Laparoscopic Surgery 2008;1:6-8 